\title{
Polyphenolic rich extract from Perilla Frutescens promotes caspase-dependent apoptosis in melanoma cells
}

\author{
Soon-Jae Kwon ${ }^{1}$, Hyun-Dong Cho ${ }^{1}$, Ju-Hye Lee ${ }^{2}$, Seong-Min Hong ${ }^{3}$, Il-Yun Jeong ${ }^{4}$, \\ Kwang-Deog Moon ${ }^{1}$, Kwon-Il Seo ${ }^{5 *}$ \\ ${ }^{1}$ School of Food Science and Biotechnology, Kyungpook National University, Daegu 41566, Korea \\ ${ }^{2}$ Functional Food and Nutrition Division, Dept. of Agro-Food Resource, National Academy of Agricultural Science, Rural \\ Development Administration, Wanju 54875, Korea \\ ${ }^{3}$ Institute of Agricultura Life Sciences, Dong-A University, Busan 49315, Korea \\ ${ }^{4}$ Advanced Radiation Technology Institute, Korea Atomic Energy Research Institute, Jeongup 34057, Korea \\ ${ }^{5}$ Department of Biotechnology, Dong-A University, Busan 49315, Korea
}

\begin{abstract}
This study aimed to assess the inhibitory potential of Perilla frutescens methanolic extract (PE) and its fractions towards melanoma cells as an herbal medicine. PE $(100-400 \mu \mathrm{g} / \mathrm{mL})$ effectively decreased the viability of the mouse and human melanoma cells (B16 and SK-MEL-2, respectively), whereas, HaCaT human keratinocytes remained un-damaged. It also induced B16 cell apoptosis, as determined by flow cytometry, Hoechst 33258 staining, and DNA fragmentation. Amongst PE fractions, ethyl acetate fraction (PEEF) displayed the most significant anticancer activity in B16 cells. It also exhibited a significant proliferation inhibitory effect on B16 cells as compared to the butanol (PEBF) and water fractions (PEWF). Furthermore, PEEF induced apoptotic cell death, through increased nuclei condensation, DNA fragmentation, and sub-G1 cell cycle arrest. PEEF-induced apoptosis was observed to be involved with the up-regulation of pro-apoptotic caspase-3, -9, Bax, and cleaved PARP, and the down-regulation of anti-apoptotic Bcl-2 protein levels. The total phenolic contents of PEEF were 2.87 and 5.39 times higher than those of PEBF and PEWF. The findings demonstrated that phenolic compound-rich PEEF induced caspase-dependent apoptosis in melanoma cells, and that it could be used as an herbal medicine and functional food material.
\end{abstract}

Key words : Anticancer, Apoptosis, Melanoma, Perilla frutescens, Polyphenols

\section{Introduction}

Perilla frutescens, an annual herb with a distinctive aroma and taste, has been cultivated for centuries in eastern Asia(1). Traditionally, it was consumed as an herbal medicine to treat sweating, cough, diuresis, food poisoning, stomachache, and anodynia. However, recently, $P$. frutescens leaves have been used as a flavor enhancer, pickled vegetable, and for beverages or tea(2). Asif (2012) reported that $P$. frutescens comprises of several phenolic compounds including

*Corresponding author. E-mail : kseo@dau.ac.kr Phone : 82-51-200-7565 Fax : 82-51-200-7505

Received 3 May 2019; Revised 9 July 2019; Accepted 18 July 2019.

Copyright (c) The Korean Society of Food Preservation. All rights reserved. rosmarinic acid, luteolin, apigenin, vanilic acid, cimidahurinine, and caffeic acid(3). The plant leaves have been used as a traditional Chinese herbal medicine for treating cold, cough, and food poisoning(3). Further, numerous studies have been shown that $P$. frutescens exert anti-inflammatory effect in murine macrophage(4), antibacterial effect in Staphylococcus aureus(5), antioxidant effect(6), antidepressantlike effect(7), anti-liver injury in d-galactosamine-sensitized mice(8), and antimicrobial activity(9). However, only few studies have reported anticancer effects of $P$. frutescens and its fractions.

Melanoma, a skin cancer type, usually arises from melanocytes in the epidermis(10). It is one of the most common cancer type in western countries, especially North America, Europe, and Latin America; due to the climate(11). Melanoma could occur not only of the skin, but also of the 
eyes or any area that is comprised of melanocytes. There are 2 major causes of melanoma: genetic factors and exposure to sun's ultraviolet (UV) light. Recently, melanoma's incidence rate has been increasing in East Asia, including South Korea(12). The early stage of melanoma could be treated by surgery; however, chemo- and immune-therapy might be required after the melanoma cells have spread to other organs. Recently, many studies have reported that natural products could effectively inhibit melanoma tumor growth(13,14). However, mechanisms underlying the effect of $P$. frutescens in inducing melanoma cell death remains unknown.

Therefore, the study was aimed to determine the anticancer activity of $P$. frutescens methanol extract and its fractions on B16 and SK-MEL-2 melanoma cells. Additionally, the findings propose that $P$. frutescens and its fractions could be developed as functional food materials for melanoma cancer prevention.

\section{Materials and methods}

\section{Preparation of $P$. frutescens methanolic extracts} and its fractions

Samples were prepared form $P$. frutescens as previously described(15). The above-ground portion of plant was extracted with methanol at room temperature for over 3 days. After filtration, the methanolic extract (PE) was evaporated and partitioned sequentially with 2 organic solvents: ethyl acetate (PEEF), and butanol (PEBF). The final portion derived after all the partitioning was the aqueous residue fraction (PEWF).

\section{Determination of total phenolic content}

Total phenolics were determined using the Folin-Ciocalteau reagent(16). $P$. frutescens methanolic extract fraction $(0.1 \mathrm{~mL})$ were diluted to $0.9 \mathrm{~mL}$ with distilled water and to it, Folin-Ciocalteau reagent $(0.1 \mathrm{~mL})$ was added. After $5 \mathrm{~min}$, $7 \%$ sodium carbonate $(1 \mathrm{~mL})$ was added and the contents were thoroughly mixed. After color development, absorbance measured at $760 \mathrm{~nm}$, by a UV/Vis spectrophotometer (Mecasys, Daejeon, Korea) after 120 min using gallic acid as a standard. The total phenol concentration was expressed as $\mu \mathrm{g} / 100 \mathrm{~mL}$ of dried PE and its fractions.

\section{Cell culture}

B16 mouse melanoma cell lines were obtained from the
Korea Cell Line Bank (Seoul National University, Seoul, Korea), whereas, SK-MEL-2 human melanoma cell lines and $\mathrm{HaCaT}$ human keratinocyte cells were procured from American Type Culture Collection (ATCC, Rockville, MD). The cells were cultured in Dulbecco's modified Eagle's medium (DMEM) supplemented with $10 \%$ fetal bovine serum (FBS), penicillin (100 IU/mL), and streptomycin (100 $\mathrm{\mu g} / \mathrm{mL})$ and RPMI-1640 medium containing d-glucose, $2 \mathrm{mM}$ l-glutamine was supplemented with $10 \%$ FBS, and 1\% (v/v) penicillin - streptomycin, in a humidified atmosphere of $5 \%$ $\mathrm{CO}_{2}$, at $37^{\circ} \mathrm{C}$.

\section{Sulforhodamine B assay}

Cell viability was determined by following previously described procedures(17). Several PE and PEEF concentrations were added for $24 \mathrm{~h}$. The cells were fixed with $50 \%$ trichloroacetic acid (Sigma-Aldrich, St. Louis, MS, USA) to terminate the reaction. The cell suspension was added with $0.4 \%$ SRB (Sigma-Aldrich) in $1 \%$ acetic acid (Daejeong, Kyunggi-do, Korea). After $1 \mathrm{~h}$ of incubation, the plates were washed, and the dyed cells were dissolved with $10 \mathrm{mM}$ Tris buffer (pH 10.5, Sigma-Aldrich). The 96 well plate was read using a micro-plate reader $(540 \mathrm{~nm})$ to obtain the absorbance.

\section{Flow cytometry assay}

The cells were seeded at a density of $1 \times 10^{6}$ cells in 6-well plates and cultured for $24 \mathrm{~h}$ in DMEM. Following this, the cells were treated with indicated sample concentrations for $24 \mathrm{~h}$. For measuring the sub-G1 populations, the cells were collected and fixed in ice-cold $70 \%$ ethanol in media and stored at $4{ }^{\circ} \mathrm{C}$ overnight. After re-suspension, the cells were washed and incubated with RNase (1 $\mu \mathrm{L}, 1 \mathrm{mg} / \mathrm{mL}$ ), propidium iodide (20 $\mu \mathrm{L}, 1 \mathrm{mg} / \mathrm{mL})$, and phosphate-buffered saline (PBS, $500 \mathrm{~mL}$ ) at $37^{\circ} \mathrm{C}$ for $30 \mathrm{~min}$. Following the staining process, FACSan flow cytometer (Becton Dickinson, Mountain View, CA, USA) was used to analyze sub-G1 populations.

\section{Morphological apoptosis}

Characteristic apoptotic morphological changes were assessed by fluorescent microscopy using bis-benzimide (Hoechst 33258, Sigma-Aldrich) staining(18). The cells were plated at density of $5 \times 10^{5}$ cells/well in 6 well plates, and then treated with PE and PEEF for $24 \mathrm{~h}$. After harvesting, the cells were washed twice with PBS and stained with 200 $\mu \mathrm{L}$ bis-benzimide $(1 \mu \mathrm{g} / \mathrm{mL})$ for $10 \mathrm{~min}$ at room temperature. Furthermore, $10 \mu \mathrm{L}$ of this suspension was placed on a glass 
slide and covered with a cover slip. The cells were examined with a fluorescence microscope (Olympus Optical Co. Ltd., Tokyo, Japan) to determine nuclei fragmentation and chromatin condensation.

\section{DNA fragmentation}

The cells were plated at a density of $2 \times 10^{6}$ cells in a 100 $\mathrm{mm}$ dish containing DMEM, and cultured for $24 \mathrm{~h}$. The cells were treated with the indicated PE and PEEF concentrations for $24 \mathrm{~h}$, and later collected by centrifugation. The pellets were lysed by DNA lysis buffer (10 mM Tris- $\mathrm{HCl}(\mathrm{pH} 7.5)$, $10 \mathrm{mM}$ EDTA (pH 8.0), 0.5\% Triton X-100, 20\% sodium dodecyl sulfate (SDS), $10 \mathrm{mg} / \mathrm{mL}$ proteinase $\mathrm{K}$ ) and then centrifuged. The supernatant was fixed in ice-cold $70 \%$ ethanol and stored at $4{ }^{\circ} \mathrm{C}$ overnight. The supernatant was extracted with phenol buffer (phenol-chloroform and phenol-chloroform-isoamylalcohol) and the pellets were incubated in TE buffer (10 mM Tris- $\mathrm{HCl}, \mathrm{pH} 7.4,1 \mathrm{mM}$ EDTA, $\mathrm{pH} 8.0)$ and RNase $(2 \mathrm{mg} / \mathrm{mL})$ for $1 \mathrm{~h}$ at $37^{\circ} \mathrm{C}$. Gel electrophoresis was performed on $2 \%$ agarose containing ethidium bromide $\left(\mathrm{GIBCO}^{\circledR} /\right.$ Invitrogen $^{\mathrm{TM}}$, GrandIsland, NY, USA). The DNA bands were visualized using a UV Transilluminator Imaging System (UVP Laboratory Products, Upland, CA, USA).

\section{Caspase inhibition assay}

The cells were plated at a density of $5 \times 105$ cells/well in a 6 well plates containing DMEM, and cultured for $24 \mathrm{~h}$. The cells were preincubated with pan-caspase inhibitor $\mathrm{z}$-VAD-fmk for $2 \mathrm{~h}$, followed by treatment with various PEEF concentrations for $24 \mathrm{~h}$. Determination of growth inhibition and SRB assay measurement was carried out by fixing the cells with $50 \%$ trichloroacetic acid to terminate these actions following which $0.4 \%$ SRB in $1 \%$ acetic acid was added to each well. The plates were washed following $1 \mathrm{~h}$ incubation and the dyes were dissolved with $10 \mathrm{mM}$ Tris buffer. Following this, the 96-well plates were read using a micro-plate reader $(540 \mathrm{~nm})$ to obtain the absorbance.

\section{Western blot analysis}

Western blot analyses were performed as described previously(19). The cells were plated at a density of $2 \times 10^{6}$ cells in a $100 \mathrm{~mm}$ dish and cultured for $24 \mathrm{~h}$ in medium. Following this, the cells were treated with various PEEF concentrations for $24 \mathrm{~h}$, followed by centrifugation. The resulting pellets were lysed with lysis buffer $(50 \mathrm{mM}$ Tris- $\mathrm{HCl}, 150 \mathrm{mM} \mathrm{NaCl}, 1 \mathrm{mM}$ EDTA, $50 \mathrm{mM} \mathrm{NaF}, 30$
$\mathrm{mM} \mathrm{Na} \mathrm{P}_{2} \mathrm{O}_{7}, 1 \mathrm{mM}$ PMSF, $2 \mu \mathrm{g} / \mathrm{mL}$ of aprotinin) for 30 min on ice. The protein content of the supernatant was measured using a BCA protein assay kit. Briefly, $10 \mu \mathrm{g}$ of protein samples were loaded per lane and separated by $12 \%$ SDS-polyacrylamide gel electrophoresis (PAGE) at $100 \mathrm{~V}$ of constant voltage/slab for $1.5 \mathrm{~h}$. Furthermore, the proteins were transferred on to nitrocellulose membranes and blocked with 2.5 and $5 \%$ BSA for $1 \mathrm{~h}$ at $37^{\circ} \mathrm{C}$. The membranes were then incubated with primary antibody at $4^{\circ} \mathrm{C}$ overnight. Primary antibodies anti-Bax (Santa Cruz sc-493), anti-Bcl 2 (Santa Cruz sc-492), anti-PARP (Santa Cruz sc-7150), anti-caspase-3 (Santa Cruz sc-7148), anti-caspase-8 (Santa Cruz sc-7890), anti-caspase-9 (Santa Cruz sc-7885) and anti- $\beta$ actin (Santa Cruz sc-47778) were used at 1:1,000 dilution. Finally, the membranes were treated with secondary antibodies for $1 \mathrm{~h}$ at $4{ }^{\circ} \mathrm{C}$. Secondary antibodies, goat anti-rabbit IgG (AP132P) and goat anti-IgG (AP124P) (Millipore, MA, USA) were used at 1:10,000 dilution. The membranes were washed with T-TBS after each antibody binding reaction and, each protein was detected with an ECL reagents kit (Santa Cruz Biotechnology, Inc.).

\section{Statistical analysis}

Data were analyzed by Student's t-test to evaluate the significant differences. Levels of ${ }^{*} \mathrm{p}<0.05$ and ${ }^{*} \mathrm{p}<0.01$ were regarded as statistically significant.

\section{Results}

\section{PE treatment inhibits the growth of melanoma} cells

Initially, the ability of PE to inhibit B16 and SK-MEL-2 cell growth was investigated. The cells were treated with $400 \mathrm{\mu g} / \mathrm{mL}$ PE for $24 \mathrm{~h}$. The PE effect on cell proliferation was evaluated by assessing morphological changes and sulforhodamine B (SRB) assay. The results revealed that the viability of B16 and SK-MEL-2 melanoma cells decreased with PE treatment (Fig. 1A). Whereas, HaCaT human keratinocytes were undamaged by high $\mathrm{PE}$ concentration. Phase-contrast microscopy revealed significant morphological changes in B16 and SK-MEL-2 melanoma cells due to PE treatment. The control cells, on the contrary, maintained a regular shape and size. Following treatment with $400 \mu \mathrm{g} / \mathrm{mL}$ PE, decreased cell number, irregular cell shape, and weakened cell adhesion was observed (Fig. 1B). These results indicated that PE inhibited B16 and SK-MEL-2 cell proliferation without significant toxicity in $\mathrm{HaCaT}$ human keratinocytes. 
(A)
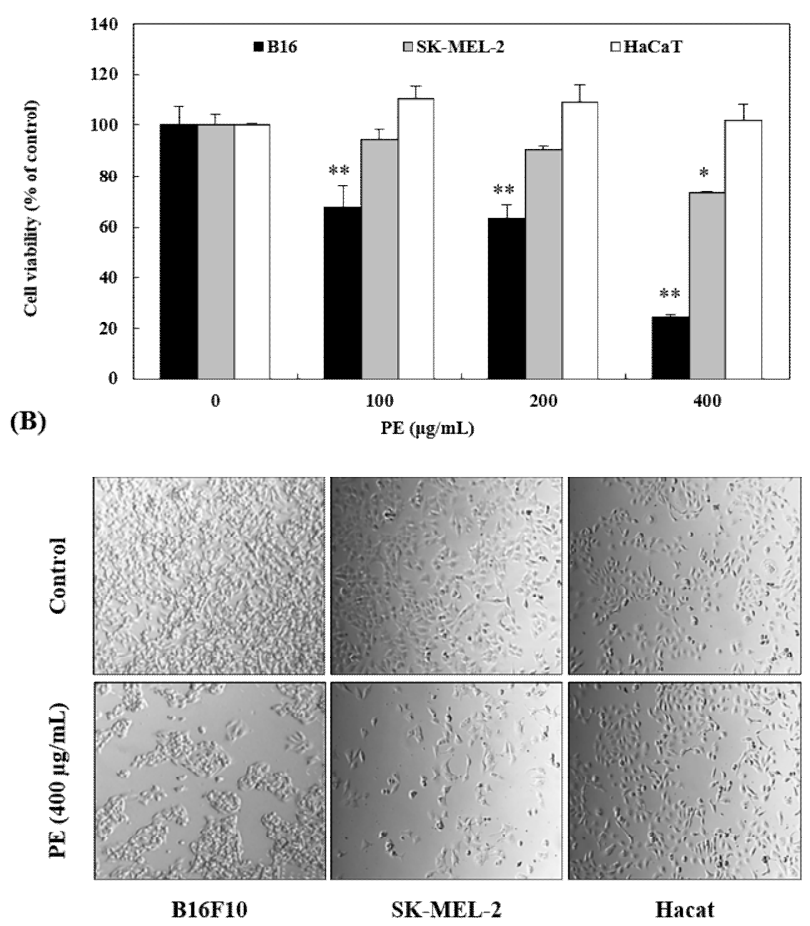

Fig. 1. Effect of $P$. frutescens methanolic extract (PE) on the growth of keratinocyte and melanoma cells.

(A) Keratinocyte and melanoma cells were treated with various concentrations of PE for $24 \mathrm{~h}$, and cell viability was determined by SRB assay. Data values were expressed as mean $\pm \mathrm{SD}(\mathrm{n}=3)$. Significant differences were compared with the control at ${ }^{*} \mathrm{p}<0.05$ using the student's t-test. (B) Cell morphology was visualized by inverted microscopy $(\times 200)$.

\section{PE induces melanoma cell apoptosis}

PE-induced growth inhibition of B16 and SK-MEL-2 cells via apoptosis was confirmed by flow cytometry, Hoechst 33258 staining, and DNA fragmentation assay. Cell proliferation in sub-G1 peak was noted as dramatically increased against B16 mouse melanoma cells (Fig. 2A). This proportion was also increased in SK-MEL-2 human melanoma cells, however, the rate of peak increase was lower than that of B16 cells. Furthermore, PE treatment $(400 \mu \mathrm{g} / \mathrm{mL})$ not only significantly increased chromatin condensation and apoptotic body formation, but also DNA fragmentation in only B16 melanoma cells (Fig. 2B, 2C). The data suggested that cell proliferation inhibitory effect of $\mathrm{PE}$ in $\mathrm{B} 16$, is related to apoptosis.

\section{PEEF treatment inhibits the growth of B16 melanoma cells}

To identify more specific cancer inhibitory effect, PE was partitioned using ethyl acetate (PEEF), butanol (PEBF), and water (PEWF), and the anticancer activity of each fraction was compared. The melanoma cells and keratinocytes were treated with $0,250,500$, and 1,000 $\mathrm{\mu g} / \mathrm{mL}$ of different PE fractions for $24 \mathrm{~h}$, and the cell viability was analyzed by SRB and morphological assays. B16 cell viability was noted to significantly decrease with PEEF treatment (in concentrations 75-300 $\mathrm{\mu g} / \mathrm{mL}$ ), whereas, PEBF and PEWF did not affect significant cytotoxicity in B16 cells (Fig. 3A). However, HaCaT human keratinocytes incubated with PEEF, were undamaged in concentrations of 75-300 $\mu \mathrm{g} / \mathrm{mL}$ (Fig. 3B). Cell morphology was assessed using a phase-contrast microscope which revealed significant morphological changes in B16 melanoma cells due to PEEF treatment. In contrast, $\mathrm{HaCaT}$ cells maintained a regular shape and size (Fig. 3C). The results indicated that PEEF selectively inhibits the growth of B16 melanoma cells without significant toxicity in HaCaT keratinocytes.

\section{PEEF induces apoptosis in B16 mouse melanoma} cells

PEEF-induced apoptosis in B16 mouse melanoma cells was confirmed by flow cytometry, Hoechst 33,258 staining, and DNA fragmentation assessment. As shown in Fig. 4A, the sub-G1 peak was significantly increased in B16 mouse melanoma cells. Furthermore, $300 \mathrm{\mu g} / \mathrm{mL}$ PEEF induced morphological changes such as nucleus shrinkage, chromatin condensation, and apoptotic body formation (Fig. 4B). Moreover, DNA fragmentation (a distinct feature of apoptosis) was identified using 2D agarose gel electrophoresis. The DNA ladder pattern in PEEF-treated cells was indicative of typical internucleosomal fragmentation, particularly after treatment with $300 \mu \mathrm{g} / \mathrm{mL}$ PEEF (Fig. 4C). These findings demonstrated that PEEF-induced B16 cell growth inhibition is associated with apoptosis.

PEEF-induced apoptosis in B16 melanoma cells through caspase-dependent pathway

To confirm the involvement of caspase proteins in PEEF-induced apoptosis, B16 cells were pretreated with 10 $\mu \mathrm{M}$ pan-caspase inhibitor, $\mathrm{z}$-VAD-fmk; before PEEF treatment. As presented in Fig. 5A, z-VAD-fmk pre-treatment significantly prevented PEEF-induced cell death as compared to the cells exposed to PEEF alone. Moreover, caspases-3, -8 , and -9 activations were monitored by western blotting to elucidate the mechanism underlying PEEF-induced apoptosis in B16 cells. Furthermore, PEEF increased the protein expression of caspase- 3 and -9 except for caspase- 8 (Fig. 5B). It also down-regulated anti-apoptotic Bcl-2 proteins, and up-regulated pro-apoptotic Bax and cleaved- 
(A)

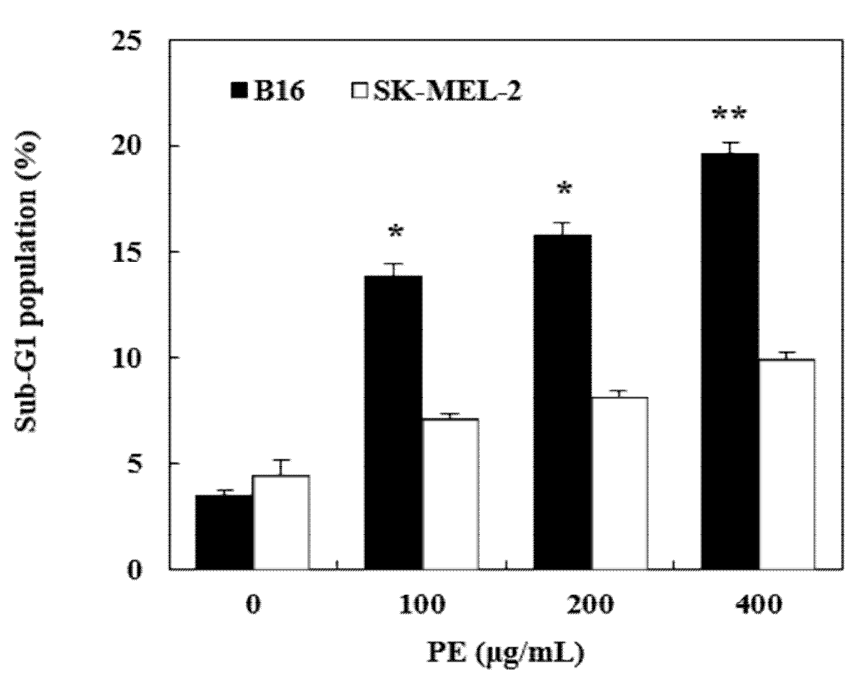

(C)
(B)

\section{B16F10}
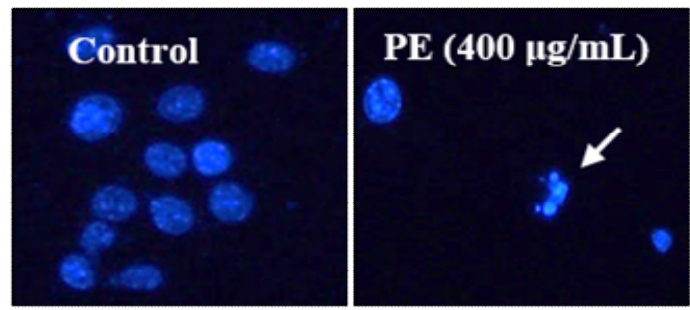

SK-MEL-2

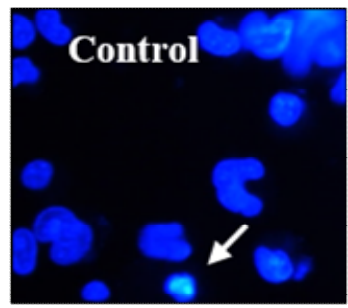

PE $(400 \mu \mathrm{g} / \mathrm{mL})$

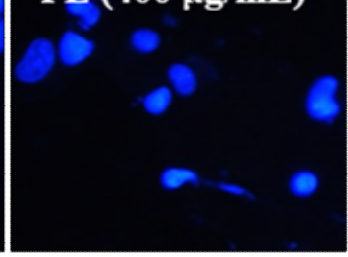

SK-MEL-2
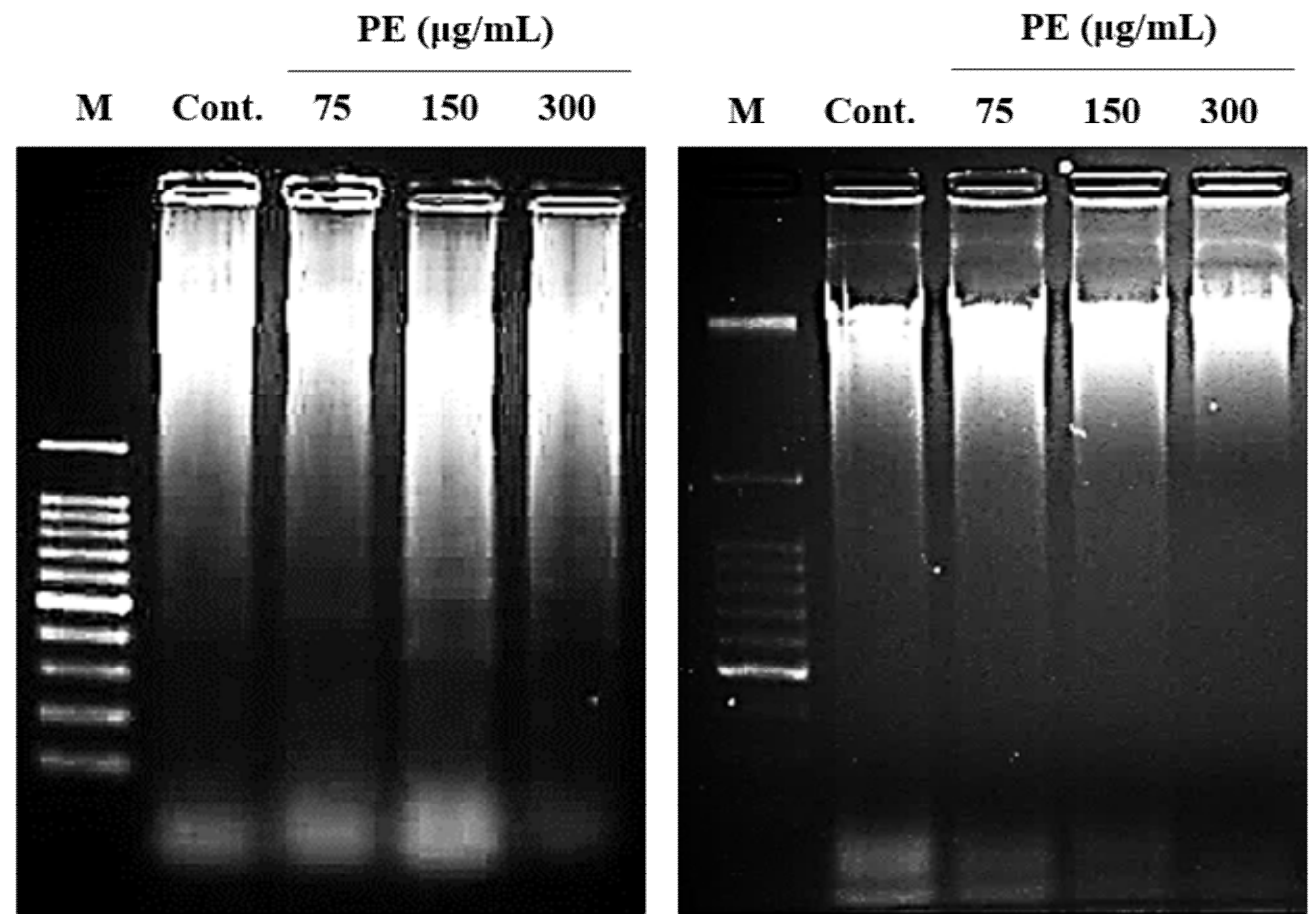

Fig. 2. Effect of $P$. frutescens methanolic extract $(\mathrm{PE})$ on the induction of apoptotic cell death in melanoma cells.

(A) Sub-G1 cell population was analyzed by flow cytometry. (B) Nuclear fragmentation was assessed by fluorescent microscopy using bis-benzimide (Hoechst 33258) (C) DNA fragmentation was observed by $2 \%$ agarose gel electrophoresis. Data values are expressed as the means \pm S.D. $(\mathrm{n}=6)$. Significant differences were compared with the control at ${ }^{*} \mathrm{p}<0.05$ and ${ }^{*} \mathrm{p}<0.01$ by Student's t-test.

PARP protein expression (Fig. 5C). The results suggested that caspases-3 and -9 activation along with the regulation of Bcl-2 family proteins were involved in PEEF-induced apoptosis of B16 cells.
PEEF contains higher total phenolic contents than other fractions

The total phenolic contents of the PEEF, PEBF, and PEWF were $44.27,15.4$, and $8.20 \mathrm{mg} / \mathrm{GAE}$ (gallic acid equivalent) 
g, respectively (Table 1). Amongst PE fractions, PEEF displayed the highest total phenolic contents. The results indicated that the phenolic compounds of PEEF may be involved in PEEF-induced apoptotic death of B16 mouse melanoma cells.

(A)

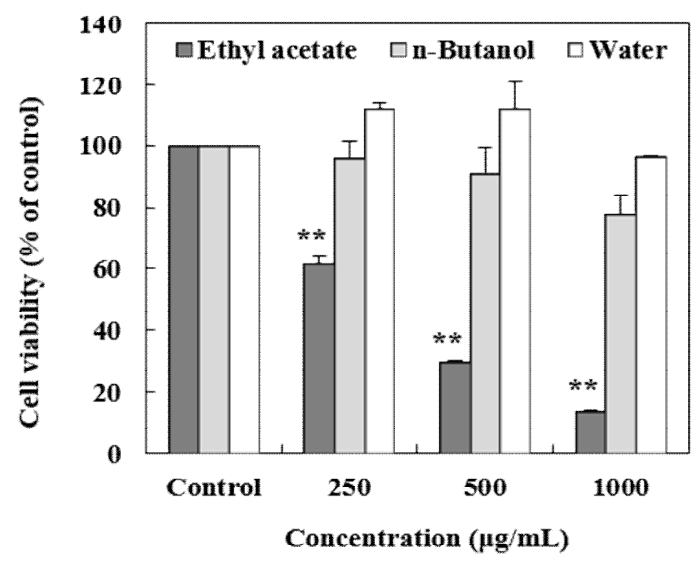

(C)

B16F10

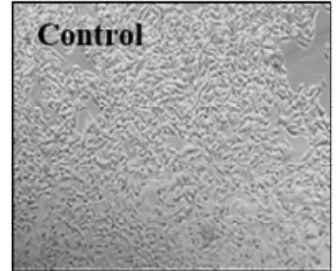

There are 2 major cell death pathways: apoptosis and necrosis. Necrosis is a form of traumatic cell death that results from acute cellular injury(20). In contrast to apoptosis (programmed cell death) it results from internal cellular signal pathway. Unlike necrosis, apoptosis confers advantages

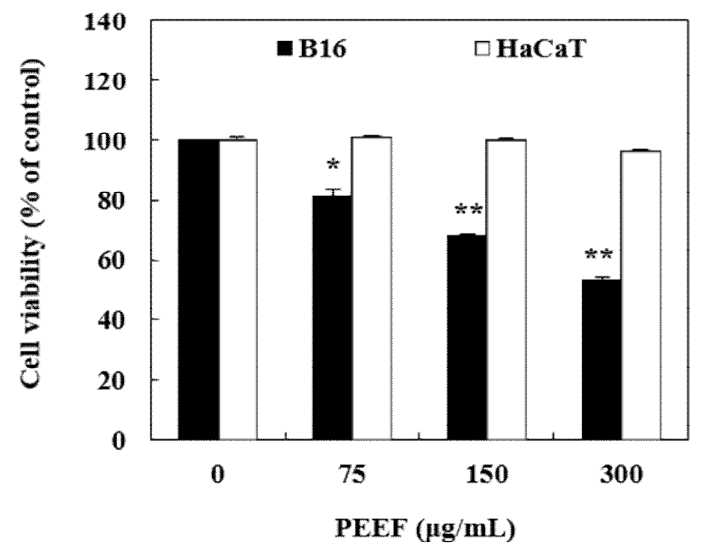

HaCaT
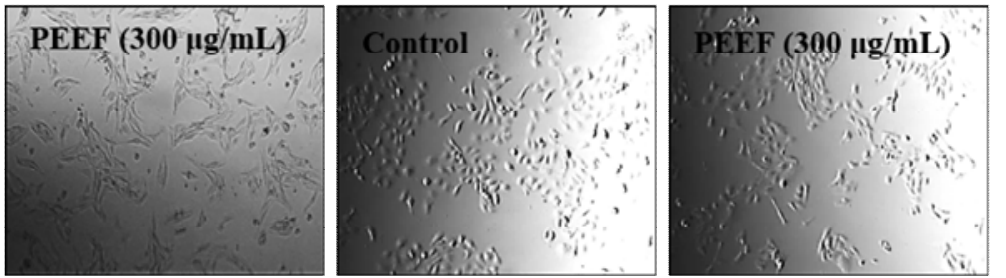

Fig. 3. Effects of $P$. frutescens methanolic extract ethyl acetate fraction (PEEF) on the growth of keratinocyte and melanoma cells.

(A) B16 melanoma cells were treated with various fractions of PE for $24 \mathrm{~h}$, and cell viability was determined by SRB assay. (B) B16 melanoma and keratinocyte cells were treated with various concentrations of PEEF for $24 \mathrm{~h}$, and cell viability was determined by SRB assay. Significant differences were compared with the control at ${ }^{*} \mathrm{p}<0.05$ and ${ }^{* *}$ p $<0.01$ by Student's t-test. (C) Cell morphology was visualized by inverted microscopy $(\times 200)$.

\section{Discussion}

Nowadays, the number of studies reporting the detection of compounds from natural materials to replace the existing chemotherapeutic agents is steadily increasing. These natural materials derived reagents have been observed to induce apoptosis in various cancer cell lines. Several studies have reported that $P$. frutescens and its derived compounds, possess various bioactive activities. However, only few studies displaying that PEEF exerts anticancer effects against melanoma cells, have been published. Therefore, the anticancer activities of $P$. frutescens extract and its fractions in melanoma cells were investigated in the present study. during an organism's life cycle(21). Apoptosis produces cell fragments called apoptotic bodies that are engulfed by phagocytic cells and are quickly removed before the contents spill out onto the surrounding cells and cause damage. Generally, apoptosis causes distinct cell morphology changes such as blebbing, cell shrinkage, sub-G1 population accumulation, chromatin condensation, and DNA fragmentation(22). Previous investigations have revealed that $P$. frutescens leaf extract increases apoptosis in human hepatocarcinoma HepG2 cells(23), and markedly reduces tumorigenesis in a murine model(24). In the present study, 200-400 $\mu \mathrm{g} / \mathrm{mL}$ PE inhibited B16 mouse melanoma cells growth and significantly increased cell number in sub-G1 
(A)

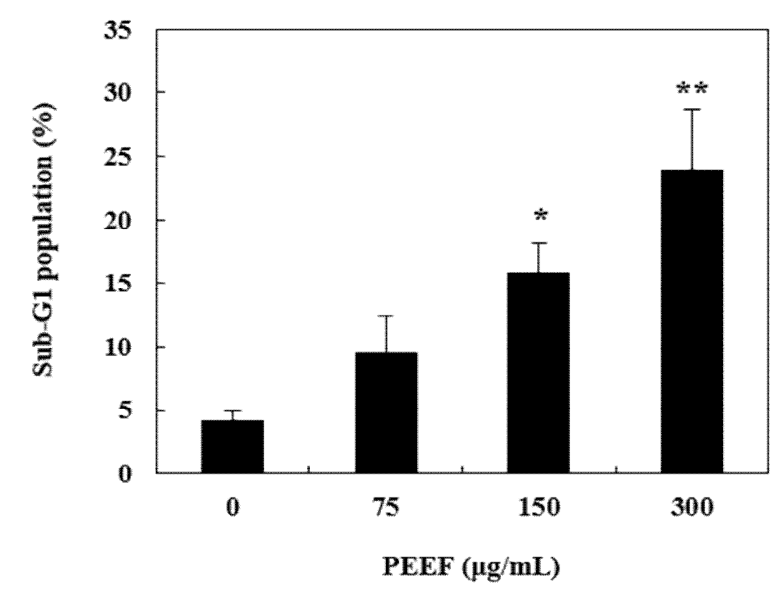

(B)
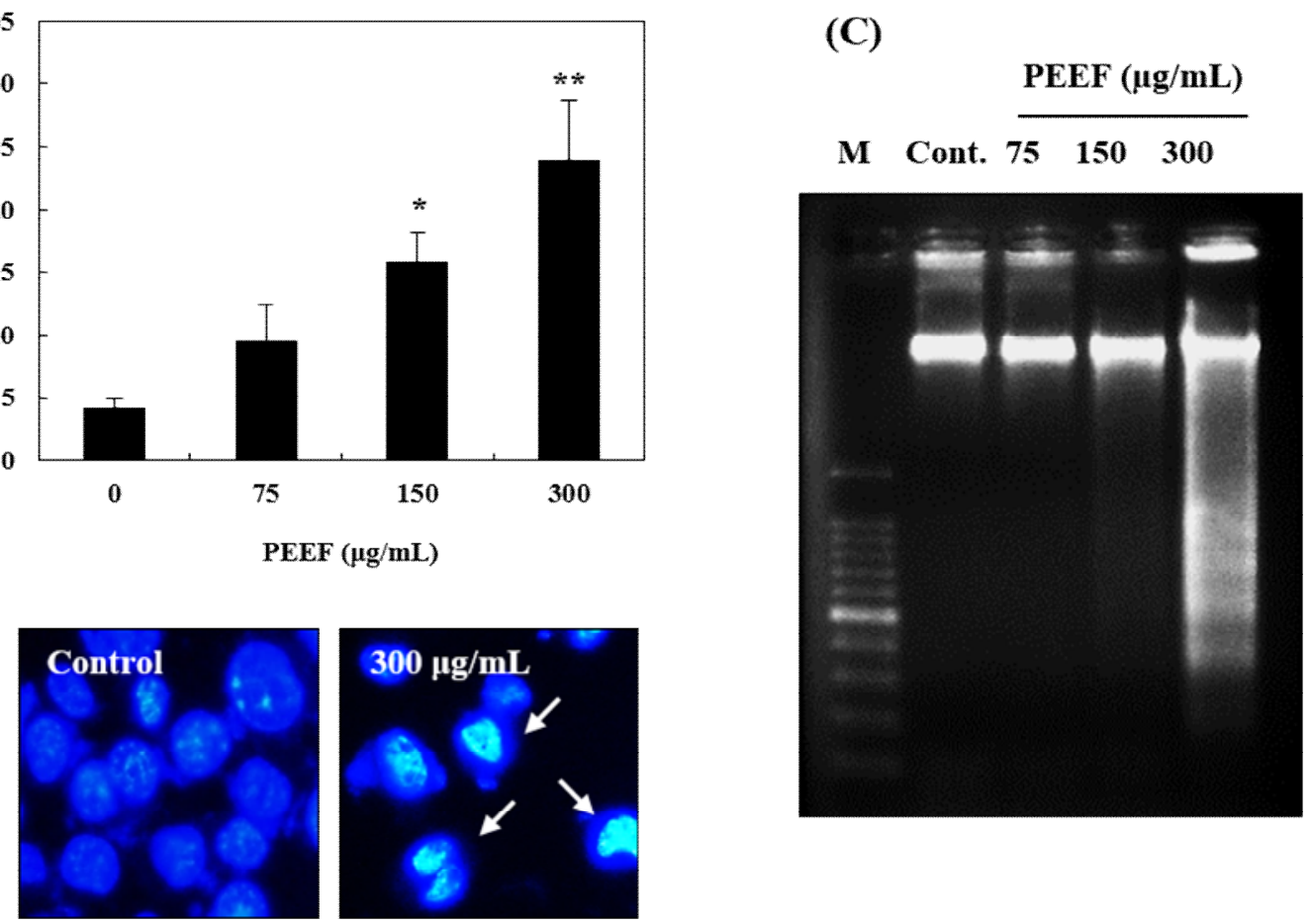

Fig. 4. Effect of $P$. frutescens methanolic extract ethyl acetate fraction (PEEF) on the induction of apoptotic cell death in melanoma cells.

(A) Sub-G1 cell population was analyzed by flow cytometry. (B) Nuclear fragmentation was assessed by fluorescent microscopy using bis-benzimide (Hoechst 33258) (C) DNA fragmentation was observed by $2 \%$ agarose gel electrophoresis. Data values are expressed as the means \pm S.E. $(\mathrm{n}=6)$. Significant differences were compared with the control at ${ }^{\star} \mathrm{p}<0.05$ and ${ }^{*} \mathrm{p}<0.01$ by Student's $\mathrm{t}$-test.

phase in a dose-dependent manner, indicating the presence of apoptotic cells. Hoechst staining disclosed that PE-treated B16 cells acquired apoptotic bodies and underwent nuclei condensation. It was also demonstrated that PE induced apoptosis by promoting DNA fragmentation. Interestingly, PE did not display significant increase of sub-G1 population, nuclei condensation, and DNA fragmentation in SK-MEL-2 human melanoma cells. Kwak et al. (25) reported that ethanol extract of $P$. frutescens leaf $(500-1,000 \mu \mathrm{g} / \mathrm{mL})$ induced DNA fragmentation and cell cycle arrest in HL-60 human leukemia cells. Although further studies are required to identify the precise cancer inhibition mechanism of PE in SK-MEL-2 cells, these results indicate that PE suppresses the proliferation of mouse and human melanoma cells through different pathways.

Apoptosis commonly promotes caspase activation through a mitochondria-dependent pathway(26). During apoptosis, caspases act as important apoptotic signaling factors activated by Bcl-2 family protein expression(27). Recently, studies have reported that compounds derived from natural materials can activate pro-apoptotic signaling pathways $(15,19,28)$. Previous reports have indicated that $P$. frutescens leaf extract induced apoptosis in human leukemia(25) and human hepatoma cells(29) through caspase- and mitochondriadependent pathways at $100-1,000 \mu \mathrm{g} / \mathrm{mL}$ concentrations. However, results from the present study displayed that PEEF induced apoptosis through a caspase-dependent pathway.

PEEF activated caspase- 3 and -9 , but not caspase-8. Moreover, it down-regulated pro-apoptotic $\mathrm{Bcl}-2$ protein expression levels, while anti-apoptotic Bax and cleaved PARP proteins were up-regulated. Typically, initiator caspase activation leads to the proteolytic activation of downstream effector caspases. The intrinsic apoptotic pathway is initiated by mitochondria membrane permeabilization and release of cytochrome $\mathrm{c}$ into the cytoplasm. Cytochrome $\mathrm{c}$ then forms apoptosomes and activates the caspase cascade through caspase-9. The extrinsic apoptotic pathway-activated caspase- 8 then directly cleaves procaspase- $3 / 7$ or other executioner caspases, eventually leading to apoptosis. Caspase-8 can also cleave the BH-3-only protein Bid, resulting in truncated Bid (t-Bid) that then moves to the mitochondria and induces cytochrome c release, leading to the activation of caspase- 9 and -3(26). These data suggested PEEF-induced apoptotic cell death to be triggered by intrinsic apoptosis signals, 
(A)

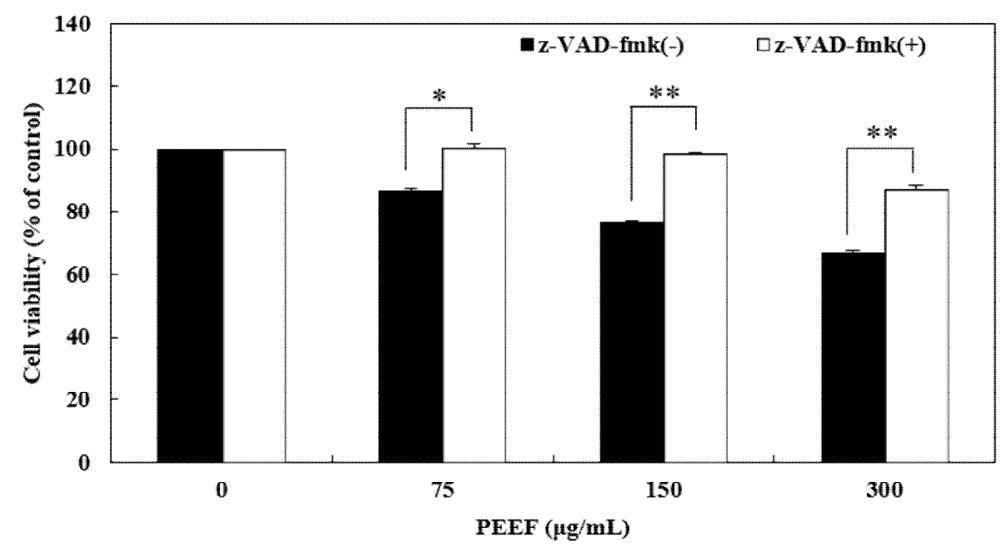

(B)

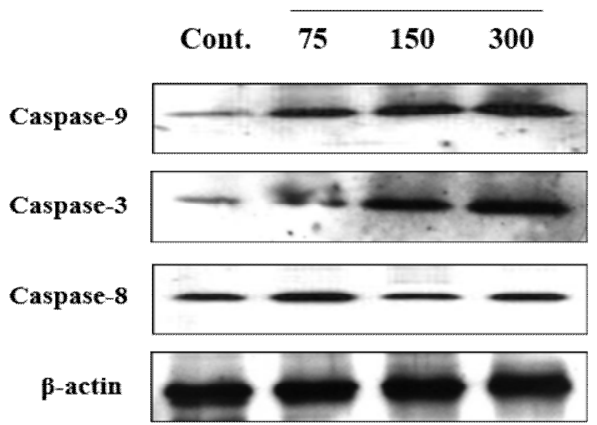

(C)

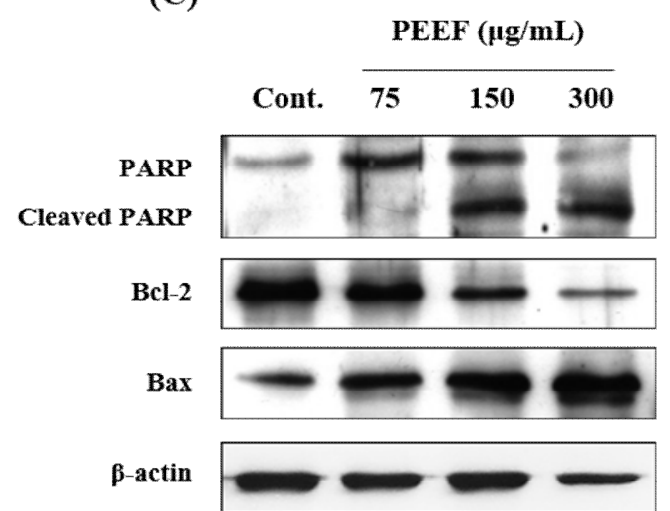

Fig. 5. Effect of $P$. frutescens methanolic extract ethyl acetate fraction (PEEF) on activation of intrinsic apoptosis in B16 melanoma cells. (A) B16 melanoma cells were pre-treated with $5 \mu \mathrm{M} \mathrm{z}$-VAD-fmk for $2 \mathrm{~h}$, followed by treatment with PEEF. (B) Protein levels of caspase-9, -3 and -8 were analyzed by western blot using specific antibodies following treatment with PEEF in B16 melanoma cells. (C) Expression of PARP, Bcl-2 and Bax in cells treated with PEEF in B16 melanoma cells as detected by western blotting.

including caspase activation.

A previous study has demonstrated that $P$. frutescens is a rich source of phenolic compounds such as apigenin, ascorbic acid, beta carotene, caffeic acid, citral, dillapiol, elemicin, limonene, luteolin, myristicin, perillaldehyde, protocatechuic acid, quercetin, rosmarinic acid, perilla ketone, elsholzia ketone, isoegomaketone, naginata ketone, and safrole(3). The phytochemical constituents of $P$. frutescens are mainly present in the essential oil(30), and the major aroma compounds are egomaketone and isoegomaketone(31). In present study, PEEF possessed higher total phenolics than the other fractions. Similar relationships were observed in suppressive effect of various phenolics on human cancer cells $(13,32)$, and other anticancer activity of $P$. frutescens extract on human cancer cells was also associated with rich polyphenolics and flavonoid contents $(25,29)$. Therefore, effective cancer suppressive activity of PEEF was supported by the presence of phenolic compounds rich content.

In conclusion, this finding suggested that $P$. frutescens could serve as a potential cancer-preventive natural medicine. However, further studies are required to investigate the active compounds in PEEF and the underlying mechanisms of the anticancer effects in melanoma cells.

Table 1. Total polyphenol content in $P$. frutescens methanolic extract (PE) fractions

\begin{tabular}{ccc}
\hline \multicolumn{3}{c}{ Total polyphenol content $(\mathrm{mg} / \mathrm{GAE} \mathrm{g})^{*}$} \\
\hline PEEF $^{1)}$ & PEBF $^{2)}$ & PEWF $^{3)}$ \\
\hline $44.27 \pm 1.17$ & $15.4 \pm 0.92$ & $8.20 \pm 0.14$ \\
\hline
\end{tabular}

Values were expressed as mean \pm S.D. $(\mathrm{n}=3)$.

${ }^{1)}$ PEEF: Ethyl acetate fraction of PE

${ }^{2)}$ PEBF: Buthanol fraction of $\mathrm{PE}$

${ }^{3}$ PEWF: Water fraction of PE

${ }^{*}$ GAE g: Gallic acid Equivalents g

\section{Conflict of interest}

The authors declare no conflict of interest. 


\section{Acknowledgement}

This study was financially supported by the Dong-A University Research Fund.

\section{References}

1. Negi VS, Rawat LS, Phondani PC, Chandra A (2011) Perilla frutescens in transition: a medicinal and oil yielding plant need instant conservation, a case study from Central Himalaya, India. Environ We Int J Sci Tech, 6, 193-200

2. Zhou XJ, Yan LL, Yin PP, Shi L,L Zhang JH, Liu YJ, Ma C (2014) Structural characterisation and antioxidant activity evaluation of phenolic compounds from cold-pressed Perilla frutescens var. arguta seed flour. Food Chem, 164, 150-157

3. Asif M (2012) Phytochemical study of polyphenols in Perilla frutescens as an antioxidant. Avicenna J Phytomed, 2, 169-178

4. Ryu JH, Son HJ, Lee SH, Shon DH (2002) Two neolignans from Perilla frutescens and their inhibition of nitric oxide synthase and tumor necrosis factor- $a$ expression in murine macrophage cell line RAW 264.7. Bioorg Med Chem Lett, 12, 649-651

5. Qiu J, Zhang X, Luo M, Li H, Dong J, Wang J, Leng B, Wang X, Feng H, Ren W, Deng X (2011) Subinhibitory concentrations of perilla oil affect the expression of secreted virulence factor genes in Staphylococcus aureus. PloS One, 6, 1-8

6. Lee JH, Park KH, Lee M, Kim H, Seo WD, Kim JY, Baek I, Jang DS, Ha TJ (2013) Identification, characterisation, and quantification of phenolic compounds in the antioxidant activity-containing fraction from the seeds of Korean perilla (Perilla frutescens) cultivars. Food Chem, 136, 843-852

7. Ito N, Nagai T, Yabe T, Nunome S, Hanawa T, Yamada $\mathrm{H}$ (2006) Antidepressant-like activity of a Kampo (Japanese herbal) medicine, Koso-san (Xiang-Su-San), and its mode of action via the hypothalamic-pituitaryadrenal axis. Phytomedicine, 13, 658-667

8. Osakabe N, Yasuda A, Natsume M, Sanbongi C, Kato Y, Osawa T, Yoshikawa T (2002) Rosmarinic acid, a major polyphenolic component of Perilla frutescens, reduces lipopolysaccharide (LPS)-induced liver injury in d-galactosamine (d-GalN)-sensitized mice. Free Radic
Biol Med, 33, 798-806

9. Kang R, Helms R, Stout MJ, Jaber H, Chen Z, Nakatsu T (1992) Antimicrobial activity of the volatile constituents of Perilla frutescens and its synergistic effects with polygodial. J Agric Food Chem, 40, 2328-2330

10. Watson M (2012) Drugs in clinical development for melanoma. Pharm Med, 26, 171-183

11. Parkin DM, Pisani P, Ferlay J (1999) Global cancer statistics. CA Cancer J Clin, 49, 33-64

12. Kim JH, Park JH, Lee DY (2015) Site distribution of cutaneous melanoma in South Korea: a retrospective study at a single tertiary institution. Int J Dermatol, 38-39

13. Rajasekar S, Park DJ, Park C, Park S, Park YH, Kim ST, Choi YH, Choi YW (2012) In vitro and in vivo anticancer effects of Lithospermum erythrorhizon extract on B16F10 murine melanoma. J Ethnopharmacol, 144, 335-345

14. Youn M, Kim J, Park S, Kim Y, Park C, Kim ES, Park K, So HS, Park R (2009) Potential anticancer properties of the water extract of Inontus obliquus by induction of apoptosis in melanoma B16-F10 cells. J Ethnopharmacol, 121, 221-228

15. Cho BO, Jin CH, Park YD, Ryu HW, Byun MW, Seo $\mathrm{KI}$, Jeong IY (2011) Isoegomaketone induces apoptosis through caspase-dependent and caspase-independent pathways in human DLD1 cells. Biosci. Biotechnol Biochem, 75, 1306-1311

16. Singleton VL, Rossi JA (1965) Colorimetry of total phenolics with phosphomolybdic-phosphotungstic acid reagents. Am J Enol Vitic, 16, 144-158

17. Skehan P, Storeng R, Scudiero D, Monks A, McMahon J, Vistica D, Warren JT, Bokesch H, Kenney S, Boyd MR (1990) New colorimetric cytotoxicity assay for anticancer-drug screening. J Natl Cancer Inst, 82, 1107-1112

18. Ricote M, Garcia TI, Fraile B, Fernandez C, Aller P, Paniagua R, Royuela M (2006) P38 MAPK protects against TNF-alpha-provoked apoptosis in LNCaP prostatic cancer cells. Apoptosis, 11, 1969-1975

19. Wan CK, Wang C, Cheung HY, Yang M, Fong WF (2006) Triptolide induces Bcl-2 cleavage and mitochondria dependent apoptosis in p53-deficient HL-60 cells. Cancer Lett, 241, 31-41

20. Golstein P, Kroemer G (2007) Cell death by necrosis: towards a molecular definition. Trends Biochem Sci, 32, 37-43

21. Edinger AL, Thompson CB (2004) Death by design: 
apoptosis, necrosis and autophagy. Curr Opin Cell Biol, 16, 663-669

22. Al RM (1998) Apoptosis and cell culture technology. Adv Biochem Eng Biotechnol, 59, 225-249

23. Lin CS, Kuo CL, Wang JP, Cheng JS, Huang ZW, Chen CF (2007) Growth inhibitory and apoptosis inducing effect of Perilla frutescens extract on human hepatoma HepG2 cells. J Ethnopharmacol, 112, 557-567

24. Ueda H, Yamazaki C, Yamazaki M (2003) Inhibitory effect of Perilla leaf extract and luteolin on mouse skin tumor promotion. Biol Pharm Bull, 26, 560-563

25. Kwak CS, Yeo EJ, Moon SC, Kim YW, Ahn HJ, Park SC (2009) Perilla leaf, Perilla frutescens, induces apoptosis and G1 phase arrest in human leukemia HL-60 cells through the combinations of death receptormediated, mitochondrial, and endoplasmic reticulum stress-induced pathways. J Med Food, 12, 508-517

26. Green DR, Reed JC (1998) Mitochondria and apoptosis. Science, 281, 1309-1312
27. Hengartner MO (2000) The biochemistry of apoptosis. Nature, 407, 770-776

28. Park SY, Cho SJ, Kwon HC, Lee KR, Rhee DK, Pyo $S$ (2005) Caspase-independent cell death by allicin in human epithelial carcinoma cells: involvement of PKA. Cancer Lett, 224, 123-132

29. Lin CS, Kuo CL, Wang JP, Cheng JS, Huang ZW, Chen CF (2007) Growth inhibitory and apoptosis inducing effect of Perilla frutescens extract on human hepatoma HepG2 cells. J Ethnopharmacol, 112, 557-567

30. Nakatsu T, Lupo JAT, Chinn JJW, Kang RKL (2000) Biological activity of essential oils and their constituents. Stud in Nat Prod Chem, 21, 571-631

31. Seo WH, Baek HH (2009) Characteristic aroma-active compounds of Korean perilla (Perilla frutescens Britton) leaf. J Agric Food Chem, 57, 11537-11542

32. Lin E, Chou H, Kuo P, Huang Y (2010) Antioxidant and antiproliferative activities of methanolic extracts of Perilla frutescens. J Med Plants Res, 4, 477-483 